Borislav Knežević

Faculty of Humanities and Social Sciences

University of Zagreb

\title{
A Few Remarks on American Studies and the American University
}

This paper presents an attempt to briefly examine the specific character of the institutional site of the disciplinary articulation of knowledge in the USA. The paper proposes that such an attempt should involve several areas of focus. First, there is a need to locate the place of the American university as a subject matter within American studies as a discipline. The second question is about the need to assess the centrality of the notion of liberal education to the American university. The third question is about the current crisis of the university and whether that crisis affects the idea of liberal education. Finally, the paper also suggests that in the context of the present-day crisis it is increasingly necessary to re-problematize the question of communication among disciplines, within or outside the context of American studies.

Key words: university, American studies, liberal education

As varied as American Studies is today, with its focus on the history of the American polity, the various and changing identities composing it, as well as the international, transnational, and global contexts wrought by and shaping the American experience, I would like to propose that more scrutiny be given to yet another subject matter relevant to American Studies, which is the specific academic world that the discipline belongs to. In other words, the academic context in which the discipline is couched (or at least the American part of it) should also be subjected to scholarly analysis under the heading of American Studies. And this not only for the purpose of disciplinary self-reflection, but also for the purpose of analyzing the massively important question of the processes of interaction between the academic and the extramural spheres in American society. 
Given the difficult and complex nature of the topic of studying education itself, my paper here can only be presented as a series of questions that I think are necessary to raise and keep returning to. The first, as I suggested initially, is that American Studies should also be a study of the American university. The second question is about the centrality of liberal education to the American university, a proposition which I think is practically or historically incontrovertible, although it is not readily clear that the idea of liberal education has had a homogeneous ideological elaboration in the history of American education. The third question is about the crisis of the university and of liberal education, a diagnosis often repeated at this time of economic turmoil among proliferating and varied discourses of declinism. In the concluding paragraphs of the paper I would like to call attention to the need to avoid the limitations of merely reactive and topical attitudes to the current condition of the university, that is, the need to provide comprehensive and sensible reads on the current trends in higher education (concerning the position of the humanities, but also the overall question of the idea of the university), which in turn also requires thinking about the American university over a longer timeframe - a task that could well be undertaken within the scope of American Studies, but one that clearly involves analysis across disciplinary borders.

As for my first point or question, I leave it to readers who are better informed than I am to judge to what extent the discipline of American Studies has been dealing with issues of scholarly analysis of the American university itself. It is easily demonstrated that there is abundant literature in the United States dealing with higher education; it is quite possible that no other contemporary national culture has devoted so much energy to academic disciplinary and institutional self-reflection. But has the university been sufficiently recognized within the disciplinary scope of American Studies as an important locus of American culture, of its economies, of its international and transnational dimensions? Perhaps these are issues more readily appreciated by those dealing with American Studies from an external perspective - at home they might be taken for granted or left to the general debate on the status of the contemporary university. 
My second point is about the continued relevance of the model of liberal education to American higher education. It is sometimes pointed out, as Martha Nussbaum has recently done in her vocal defense of the idea of liberal education, that this educational model of higher education is found in virtually no other country (17). It indeed is fair to say that liberal education is a very distinctive feature of the American university, ${ }^{1}$ if by liberal education we mean a concept that regards university education as not just or exclusively vocational, but a learning process that involves exposure to a broad range of knowledge, ${ }^{2}$ as well as the idea that the exposure to broad learning can facilitate both personal cultivation and education for life in a community. There are some voices today that suggest that the actual university practices designed to convey a liberal range of knowledge fall short of meeting the goals of personal growth and education for the community in anything but the name, insofar as it could be argued that general education requirements at American universities are but perfunctory acknowledgments of the need to provide a meaningful breadth of perspectives associated with the idea of liberal education. Be that as it may, and we must keep in mind that the situation on the ground is tremendously varied in this regard, I would like to suggest here that the idea of liberal education, even when practiced only mechanically, is an important scholarly and social resource in itself. Even exposure to a mechanically assembled plurality of disciplinary thought is preferable in

1 Undergraduate degree programs at some universities in Canada, Scotland and Ireland, and a few other countries around the world, possess some elements comparable to the higher education model commonly found at American universities, but there are also pronounced differences. In England, the most prestigious universities of Oxford and Cambridge developed a system of undergraduate education which is rather unique in terms of instruction, assessment and curricular requirements.

2 In a typical four-year program at an American university, this means taking courses across the different branches of knowledge, with a major in at least one academic discipline chosen not at admission but most often by the end of the second year of study. For the student, this involves a good deal of choice in taking courses outside their major, although there are usually certain requirements in terms of the distribution of such courses across different broad areas of knowledge (typically categorized as the humanities, the social sciences, the natural sciences). 
higher education to the principle of exclusively vocational training. Equally importantly, I would like to suggest that attempts to overregulate the content of liberal education in order to redress the presumably perfunctory deployment of the concept of liberal education would run the risk of turning out to be a resource for dogma rather than for critical thought and cultivation of the ability to relate competently to issues across a range of scholarly disciplines. Since plurality of disciplinary perspectives is attendant on the very idea of liberal education, this very plurality makes it somewhat resistant to standardization.

My third question has to do with the perception that there is currently a crisis of liberal education going on. Here I do not mean so much the charge of perfunctoriness, or the readings that relate this condition to the new priorities of university administrations that place financial issues above pedagogical ones. The crisis that I have in mind here has to do with the perception of the current condition of the university, and the question of dwindling funding (the humanities in particular feel embattled in this regard), which indeed is cause for concern. This crisis is mainly seen to have been occasioned by two historical narratives: it has been around for some time (since the 1970s, according to most accounts), ${ }^{3}$ and then exacerbated by the economic calamities in the new century. In other words, very often the root cause for the crisis is found in a shift in the development of American capitalism towards "neoliberalism" in the 1970s, which was then coupled in the last two decades by a quantum leap of contemporary capitalism into financialization, a leap that brought about massive economic turmoil. The crisis thus identified is most commonly held to affect public universities more than private ones, for the former depend more on state funding (indeed, one of the noticeable trends in the funding of state universities has been the diminishing share of public funding, and climbing tuition fees). Needless to say, the situation regarding

3 There was a good deal of declinist discourse on higher education already in the 1990s; a good example is Bill Readings' book The University in Ruins from 1996, which focused on the spreading of market imperatives in American higher education. 
public universities varies from state to state, and probably larger research universities are affected differently than lower-ranked schools. Another aspect of the crisis is that some parts of the university (such as the humanities) seem to be more impacted by the crisis than others, which is often perceived, at the very least, as affecting the quality of education, not to mention the status of individual disciplines or of the teaching profession in general.

Yet upon closer inspection, things get somewhat complicated. It would be a stretch to suggest that in general the American university is moving away from the concept of liberal education (Martha Nussbaum contends that it is not). ${ }^{4}$ The symbolic capital enjoyed by a wide pool of American universities around the world is still more than considerable, and it would be difficult to wholly explain this symbolic prestige without reference to the appeal of liberal education. Also, it is worth raising the question of whether the changing fortunes of the humanities (and the university in general) can be accounted for simply by reference to economic conditions and policies, and whether other kinds of dynamics may have contributed to the current crisis in the academic world. Any explanatory narrative of how things got to where they are now needs to come to terms with a more long-term perspective addressing more than just economic shifts. For instance, as Louis Menand suggests, the explosion of both university enrollment and employment that happened during the Golden Age in higher education (1945 to 1975) requires serious attention, especially in terms of economic growth, demographic growth, and the new importance attached to higher education by Cold War policies (and superpower rivalry). The vast expansion of the academic world in the Golden Age was unprecedented in the history of the American university, and this very fact calls for analysis from a longer-duration perspective, one which would extend even further into the past so as to furnish additional light on the current situation. Here, the long perspective may also require us to review not only the last half century but also the history of the modern university (in

$4 \quad$ Nussbaum claims that the model of liberal education "is still relatively strong, but it is under severe stress now in this time of economic hardship" (18). 
the United States), which is really only a little more than a century old, while the idea that it should be a place of equal opportunity is considerably younger still. Also, let us remember that the period after WW II seemed to offer a promise of economic, technological, and scientific progress, which is often regarded as a golden age not only in terms of higher education; this, in turn, presents us with the need, when talking about higher education in the United States, to also engage in a more focused historical analysis of the expansive dynamic of the postwar period itself.

In that regard, let's have a closer look at how the present crisis of the university manifests itself. A central area of concern is the deterioration of the structure of university employment: slowly but steadily, the percentage of part-time instructional staff has been rising since 1975, and the percentage of full-time instructional staff has been slowly but steadily dropping. ${ }^{5}$ While recently, in the period from 1997 to 2007, the total number of instructional staff rose by almost $32 \%$, two thirds of this increase was in contingent labor. ${ }^{6}$ In the period from 2000 to 2012 the overall number of jobs in American higher education rose by $28 \%$, but more of the growth was in administration and student services than in instructional staff. ${ }^{7}$ As for employment in modern languages and literatures, the number of jobs advertised annually by the

5 See the report entitled The Employment Status of Instructional Staff Members in Higher Education, Fall 2011 (published by the American Association of University Professors in April 2014). http://www.aaup.org/sites/default/files/files/AAUP-InstrStaff2011April2014.pdf. Figure 1 in the report shows that, in the period from 1975 to 2011, the share of full-time faculty (tenured and tenure-track) steadily decreased, while the share of part-time faculty steadily grew, with the share of graduate student employees remaining at more or less the same level. To complete the picture, the share of full-time non-tenure-track faculty also recorded an increase.

6 See the American Federation of Teachers report, The State of the Higher Education Workforce 1997-2007. https://www.aft.org/pdfs/highered/aa_highedworkforce0209.pdf

7 See Scott Carlson, "Administrator Hiring Drove 28\% Boom in Higher-Ed Work Force, Report Says," in The Chronicle of Higher Education, February 5, 2014. http:// chronicle.com/article/Administrator-Hiring-Drove-28-/144519 Carlson quotes the data compiled by the Delta Cost Project. 
Modern Language Association was steadily rising in the period from 1975 to 1989 (which could suggest that in some way the good times lingered on well after the end of the Golden Age), and then sharply fell in the 1990s, resumed a rising trend in the '00s, and then sharply fell again in 2008 as the most recent economic crisis hit; the peak level of 1989 has not been recovered since. ${ }^{8}$

Such data must be viewed in relation to the Golden Age, when unprecedented (and probably unrepeatable) expansion was recorded. Menand writes, for example, that more faculty were hired in the 1960s "than in the entire 325 years of American higher education prior to 1960" (64-65). Between 1945 and 1975, the number of undergraduates increased 500\%, while the number of graduate students increased 900\%; but when in the 1970s the expansion "abruptly came to a crawl, [it deposited] on generational shores a huge tenured faculty and too many doctoral programs churning out $\mathrm{PhDs}$ " (145). On the other hand, the average faculty teaching load fell from about 9 hours a week in 1960 to 4.5 hours a week in 1990 (Menand 76); this was among other things informed by a shift in university priorities whereby universities started to increasingly value research over teaching. But this also means that academic careers drastically changed over that period, which in turn gave rise to a complicated debate on how to balance research and teaching.

As the Golden Age came to an end in the 1970s, growth in American higher education slowed down considerably in most ways. There still was growth, even relatively steady growth: in the humanities, for instance, the number of bachelor's degrees has been slowly rising since the 1980s, ${ }^{9}$ which

8 See Report on the MLA Job Information List, 2011-12. MLA Office of Research. Web Publication, September 2012. http://www.mla.org/pdf/report_jil_1112.pdf

9 See http://www.amacad.org/binaries/hum_report_card.pdf. The Humanities Report Card for 2013, published by the American Academy of Arts and Sciences, which suggests that the number of bachelor's degrees in the humanities rose gradually from 1987, with a period of stagnation in the 1990s, followed by another period of gradual growth in the '00s. 
means throughout the recent crises (although it is probably likely that many humanistic disciplines had declining numbers in that period, while other humanistic programs recorded gains). Of course, the various trends of slow growth after the mid-1970s can only be more completely grasped in relation to specific attendant contexts. In recent years, for example, the student body has also grown nationwide: enrollment rose $11 \%$ between 1991 and 2001, and $32 \%$ between 2001 and 2011, with the percentage of the enrollment of the 18- to 24-year-old population rising (the latter to $42 \%$ in 2011). A significant increase in post-baccalaureate enrollment of $78 \%$ was recorded in the period from 1985 to $2011 .^{10}$ (But again, think of the Golden Age numbers!) We should, however, always remember to appreciate the fact that the dramatic rates of enrollment expansion that took place in the Golden Age are wellnigh impossible to replicate, for the simple reason that dramatic increases in enrollment are only possible when enrollment is relatively low to begin with (as it was at the beginning of the Golden Age), or when there is a significant increase in population (as there was in the postwar period).

Nevertheless, these figures do spell out a crisis in relation to the Golden Age. There is still growth in instructional staff, but it is much slower (and there is also talk of stagnation in salary levels). There is a crisis in terms of the relative weakening of the tenure-track job, and the growth of contingent jobs. There is a crisis in the sense of restructuring and department closures, affecting mostly lower-tier public universities, and predictably, much less the wealthy private schools. But there are also other kinds of crises, which are perhaps less talked about. There is, for instance, a crisis in the genre of the mission statement, or in the self-understanding of the university and its social and educational goals, a crisis commonly circumvented by reference to the vague rhetoric of excellence ${ }^{11}$ (although I am not certain that the American university in pursuit of excellence matches the penchant for quantifi-

10 See http://nces.ed.gov/fastfacts/display.asp?id=98. This is data compiled by the National Center for Education Statistics, U.S. Department of Education.

11 Bill Readings wrote extensively on the rhetoric of excellence in his 1996 book. 
cation and bureaucratization of academic work such as we are facing in the European context). There is also a crisis in the ways in which we academics now habitually think about and do research, and this crisis proceeds from the reshaping of research as an activity on the academic market. This can be exemplified by, but not reduced to, the imperative of publishing as a means of increasing the marketability of academics. More generally speaking, the exchange of scholarly ideas is now structured as a marketplace of ideas with its own rules of supply and demand, complex as those rules might be and not necessarily analogous to the rules obtaining in other types of markets. Finally, there is a sense that the economic turmoil of the last several decades has also exposed a problem deeply embedded in American academic life (but also in all academic life) — that of (re)conceptualizing, articulating and planning the parameters of academic work. The contours of the modern university in the United States (regarding its institutional structure and curricular requirements) can be traced back to the period of the late nineteenth century and the first few decades of the twentieth century. In that regard, there have been no dramatic changes since that time, and newly emerging disciplines and changing canons have been accommodated within the same basic structure. (In the meantime, higher education became a mass experience, research became a much more central aspect of academic culture and one of the cornerstones of the contemporary civilization, and the needs of organizing and funding higher education and research became much more complex.) While it could be reasonably argued that the constancy of the institutional framework of American universities over such a long period of time may have contributed to their research and teaching performance and potentials, the economic troubles of recent decades have had an unpleasant way of reminding us that higher education always requires a good deal of good planning.

To a historian assuming a detached point of view, it may appear that an appreciable deal of the present troubles stems from the failure of the universities and their administrations, but also of their academic staff, to engage in appropriate mid-term or longer-term thinking and planning (and here I do not mean the kind of planning that concerns itself with narrowly voca- 
tional education for the marketplace on the basis of topical needs, but strategic planning of the development of academic institutions). Curricular, organizational, funding, and hiring issues now often appear reactive, a matter of choices about cutting programs and redistributing the available funds. I do not presume to know how better planning should be done or made possible; necessarily, special attention should be paid to decision-making processes in academia and the role of faculty in such processes, and especially in strategic planning of institutional development. I do think, however, that it is unfortunate that in many parts of the world higher education is now experiencing dire economic restrictions at a time when it is clear that the character of knowledge is undergoing a dramatic change. What has been called globalization is increasingly asking of academics to research, think, and write across conventional disciplinary boundaries, while the massive information explosion is changing the way in which knowledge is generated, acquired, and disseminated. This calls for - and this is a point I cannot elaborate at length but can only propose here - a university informed by a solid grounding in liberal education and wary of exclusive vocationalism, a university that remains committed to education for thinking across disciplines.

A particularly important consequence of the current crisis, as well as of the responses to it, for scholarship itself is, in my opinion, the increasingly clear need for a more vigorous discussion on the disciplinary organization of knowledge. Liberal education only makes sense if there is lively cross-border traffic among disciplines, as well as a lively discussion on what such traffic means or should mean. In that regard, it is less important whether the discipline of American Studies takes a structured look at the American university itself; it is more important that such work be done in the form of appreciating the need for communication among different forms of knowledge and scholarship. If it is readily obvious that one of the most dynamic aspects of reshaping American Studies as a discipline in recent decades has been a shift towards a transnational perspective in dealing with the various meanings of 
the study of America, ${ }^{12}$ then it should be equally obvious that there is also a need to root American Studies in reflection about the American university, its social and economic contexts, its institutional makeup, and its production of academic knowledge, all of which requires an understandably varied assembly of disciplinary analyses.

\section{Works Cited}

Carlson, Scott. "Administrator Hiring Drove 28\% Boom in Higher-Ed Work Force, Report Says." The Chronicle of Higher Education. Feb. 5, 2014. <http://chronicle.com/ article/Administrator-Hiring-Drove-28-/144519>.

Fast facts. Feb. 5, 2014. <http://nces.ed.gov/fastfacts/display.asp?id=98>.

The Humanities Report Card. Feb. 5, 2014. <http://www.amacad.org/binaries/hum report_card.pdf >.

Menand, Louis. The Marketplace of Ideas. Reform and Resistance in the American University. New York: W.W. Norton, 2010.

Nussbaum, Martha C. Not for Profit. Why Democracy Needs the Humanities. Princeton: Princeton UP, 2010.

Readings, Bill. The University in Ruins. Cambridge: Harvard UP, 1996.

Rowe, John Carlos. The New American Studies. Minneapolis: U of Minnesota P, 2002. Report on the MLA Job Information List, 2011-12. MLA Office of Research. Web Publication, September 2012. Feb. 5, 2014. <http://www.mla.org/pdf/report_ jil_1112.pdf $>$.

12 One way of describing this development is as a shift from the once popular paradigm of exceptionalism in American Studies to what John Carlos Rowe called a "postnational" perspective (see the chapter entitled "Postnationalism, Globalism, and the New American Studies" in his book The New American Studies). 